\title{
Analysis of Factors that Influence the Occuration of Early Rapture of Money in Particular Patients in Pragaan Public Health Center, Sumenep Regency
}

\author{
Abdul Aziz ${ }^{1}$, Siti Farida ${ }^{2}$, \\ Byba Melda Suhita ${ }^{2}$ \\ ${ }^{1}$ Pragaan Public Health Center \\ Sumenep \\ ${ }^{2}$ Strada Indonesian Institute of \\ Health Sciences \\ Email: \\ abdulazis@gmail.com
}

Received : October $4^{\text {nd }} 2021$

Accepted : October $15^{\text {rd }} 2021$

Published : November $27^{\text {th }} 2021$

\begin{abstract}
Pregnancy is a moment that is highly desired by husband and wife. This can make the family more harmonious because it has a child who is always coveted. But in reality, sometimes pregnancy is accompanied by several obstacles, such as premature rupture of membranes. The purpose of this study is to analyzethe effect of economic status, fetal position and family support on the incidence of premature rupture of membranes in inpartu patients at the Pragaan Health Center, Sumenep Regency. The design of this research is an observational quantitative research with a cross sectional approach with the focus of the research being directed at analyzingthe effect of economic status, fetal position and family support on the incidence of premature rupture of membranes in inpartu patients at the Pragaan Health Center, Sumenep Regency. The total population of 160 respondents and a sample of 100 respondents were taken by Accidental Sampling technique. The findings show that almost half of the respondents haveeconomic status middle class category as many as 42 respondents (42\%).Almost half of the respondents experienced an anterior fetal position as many as 39 respondents (39\%). Most of the respondents have family support in the less category as many as 62 respondents $(62 \%)$. Most of the respondents experienced premature rupture of membranes as many as 56 respondents $(56 \%)$. Based on the results of the Logistics Regression analysis shows that the p-value $<0.05$ then $\mathrm{H} 1$ is accepted so it is concluded that there is an effect of economic status, fetal position and family support for the incidence of premature rupture of membranes in inpartu patients at the Pragaan Health Center, Sumenep Regency. It is hoped that both pregnant women can manage the needs and things that must be done during pregnancy until delivery, starting from maintaining a lifestyle and even monitoring the development of the fetus in order to reduce the incidence of KTD.
\end{abstract}

Keywords: Family support, premature rupture, membranes, fetal position, economic status

Copyright @ 2021 IIK STRADA Indonesia All right reserved.

This is an open-acces article distributed under the terms of the Creative Commons AttributionShareAlike 4.0 International License. 


\section{INTRODUCTION}

Pregnancy is a moment that is highly desired by husband and wife. This can make the family more harmonious because it has a child who is always coveted. But in reality, sometimes pregnancy is accompanied by several obstacles such as premature rupture of membranes. Premature rupture of membranes is the process of rupture of the membranes before the start of labor or delivery time that is more than 37 weeks or less than 36 weeks (Manuaba, 2014). Then Prawirohardjo (2015) also said that premature rupture of membranes is a state of rupture of the amniotic membranes before delivery where the gestational age has not reached 36 weeks.

Premature rupture of membranes or spontaneous / early / premature rupture of the membrane $(\mathrm{PROM})$ is a rupture of the membranes in inpartu mothers, namely when the opening in primiparas is less than $3 \mathrm{~cm}$ and in multiparas less than $5 \mathrm{~cm}$, regardless of gestational age (Nugroho, 2012). Premature rupture of membranes can occur late in pregnancy or long before delivery. The incidence of premature rupture of membranes in some areas is high, this is evidenced by the high number of referrals with cases of premature rupture of membranes by village midwives to hospitals with more adequate health facilities.

Premature rupture of membranes is very dangerous for pregnant women and their babies. The danger of premature rupture of membranes is infection occurs in the mother and baby. The rupture of the membranes leaves the baby unprotected by the amniotic membrane and exposed to contact with the outside world, which causes bacteria to enter the mother's womb and infect both mother and baby. This can be life threatening for both mother and baby. In addition, the birth of a baby that is less than the normal time causes premature babies and the risk of fetal defects is high (Kompasiana, 2014).

Based on the Indonesian health profile (2015), the Maternal Mortality Rate (MMR) is $305 / 100,000$ live births. The direct causes of maternal death are bleeding 40-60\%, preeclampsia 20$30 \%$, infection $20-30 \%$. One of the causes of infection is the incidence of premature rupture of membranes that do not get immediate treatment. Based on data from the Pamekasan Health Service in 2016 the incidence of premature rupture of membranes at Slamet Martodirejo Hospital was 563 cases, while data from the health office in 2017 showed the incidence of premature rupture of membranes at Moh. Noer as many as 354 cases, whilebased on initial data collection conducted by researchers from September - November 2017 at Moh. Noer Pamekasan, there were 69 cases of inpartu mothers with premature rupture of membranes.

Based on the results of a preliminary study conducted by researchers on October 5, 2020 at the Pragaan Health Center, Sumenep Regency to 10 respondents who had experienced premature rupture of membranes, it was found that a number of 3 respondents $(30 \%)$ during pregnancy had a breech baby, in addition to 3 respondents (30\%) \%) during pregnancy was not supported by the family to carry out integrated ANC, and also a number of 2 respondents (40\%) had low economic status so that taking care of pregnant women was very burdensome for patients and families.

The cause of premature rupture of membranes is not known with certainty, but it is possible that the predisposing factor is infection that occurs directly in the amniotic membrane or ascending from the vagina or cervix. In addition, abnormal amniotic membrane physiology, incompetent cervix, fetal position abnormalities, age of women less than 20 years and above 35 years, multigravidity/parity factors, smoking, socioeconomic conditions, antepartum bleeding, history of abortion and previous preterm delivery, history of amniotic fluid previous premature rupture, nutritional deficiencies, namely copper or ascorbic acid, excessive uterine tension, narrowing of the pelvis, maternal fatigue at work, and trauma obtained such as a history of sexual intercourse in the third trimester, internal examination and amniocentesis (Prawirohardjo, 2014).

According to Alim (2016), one of the factors that cause premature rupture of membranes is the position of the baby (18.96\%) which can occur due to unsafe delivery assistance. Then followed by economic status factor (18.22\%), family support factor (15.99\%), past history of premature rupture of membranes (15.24\%), age factor (12.27\%), parity factor $(9.67 \%)$, and the last factor was gemeli and malpresentation (4.83\%) at the Help Lawang Hospital. The position of the baby is very dominant in influencing the occurrence of premature rupture of membranes in pregnant women, it is also caused by vaginal discharge experienced by pregnant women both before pregnancy or during pregnancy, because during pregnancy the mother's body temperature increases and causes humidity in the mother's genital area, this is due to increased estrogen causing darker vaginal mucosa, 
Huda (2013) explained the results that breech had a significant effect on premature rupture of membranes at PKU Muhammadiyah Surakarta Hospital. Because the buttocks with both legs folded are larger than the head which allows the uterus to increase in tension, thereby causing the membranes to rupture prematurely.

Inadequate family economic conditions cause pregnant women and fetuses to be less able to get what they really need to support the health of the mother and fetus. The position of the fetus that is not suitable can also cause premature rupture of the membranes. And also family support plays an important role in meeting the needs of the mother and fetus where the family will fully assist everything that is needed by the mother and fetus during the early pregnancy until the delivery process. So that these factors become very important considering that pregnant women can experience premature rupture of membranes (Mulyanto, 2015).

The impact of premature rupture of membranes if not immediately treated for the mother is infection with germs from outside, and premature or preterm delivery, while the impact on the fetus is blood circulation disorders or the umbilical cord which can cause fetal distress and fetal death due to compression of the umbilical cord and oligohydramnios. (amniotic fluid is less than the amount needed or even exhausted). Based on the above conditions, the authors are interested in researching the analysis of factors that influence the occurrence of premature rupture of membranes in inpartu patients at Pragaan Health Center, Sumenep Regency.

\section{MATERIALS AND METHODS}

In this study, the researcher used an observational quantitative design with a cross sectional approach, which is a study to study the dynamics of the correlation between risk factors and effects, by approaching, observing or collecting data at once (point time approach), meaning that each subject The study was observed only once and measurements were made on the status of the character or variable of the subject at the time of examination. This does not mean that all research subjects are observed at the same time (Soekidjo, 2012). This research will analyzethe effect of economic status, fetal position and family support on the incidence of premature rupture of membranes in inpartu patients at the Pragaan Health Center, Sumenep Regency. The total population of 160 respondents and a sample of 100 respondents were taken by Accidental Sampling technique. Data analysis using Logistic Regression test.

\section{RESULT}

Table 1. Statistical test results Factors influencing the occurrence of premature rupture of membranes in inpartu patients at Pragaan Health Center, Sumenep Regency conducted by researchers on March 1-30, 2021 with a total of 100 respondents

\begin{tabular}{|c|c|c|c|}
\hline No & Variable & Sig & \multirow{2}{*}{ Constant } \\
\hline 1 & Economic Status & 0.002 & \multirow{2}{*}{0.014} \\
\hline 2 & Fetal Position & 0.005 & \\
\hline 3 & Family support & 0.012 & \\
\hline
\end{tabular}

1. The effect of economic status on the incidence of KTD

Based on the results of the Logistics Regression analysis shows that the p-value is $0.002<0.05$, then $\mathrm{H} 1$ is accepted so it can be concluded that there is the effect of economic status on the incidence of premature rupture of membranes in inpartu patients at Pragaan Health Center, Sumenep Regency

2. The effect of economic status on the incidence of KTD

Based on the results of the Logistics Regression analysis shows that the p-value is $0.005<0.05$ then $\mathrm{H} 1$ is accepted so it can be concluded that there is the effect of fetal position on the incidence of premature rupture of membranes in inpartu patients at Pragaan Health Center, Sumenep Regency

3. The effect of economic status on the incidence of KTD

Based on the results of the Logistics Regression analysis shows that the p-value is $0.012<0.05$ then $\mathrm{H} 1$ is accepted so it can be concluded that there is influence family support 
for the incidence of premature rupture of membranes in inpartu patients at the Pragaan Health Center, Sumenep Regency

\section{DISCUSSION}

\section{A. Economic Status of Inpartum Patients at Pragaan Health Center, Sumenep Regency}

The results showed that almost half of the respondents had economic status middle class category as many as 42 respondents (42\%). In addition, 38 respondents $(38.0 \%)$ haveeconomic status lower class category. While a number of 20 respondents $(20.0 \%)$ have economic status high end category.

Humans are developing and active creatures. Humans are referred to as creatures who like to work, humans work to meet their basic needs consisting of clothing, clothing, boards, and fulfill secondary needs such as higher education, vehicles, entertainment equipment and so on (Mulyanto, 2015).

Work will determine socioeconomic status because from work all needs will be fulfilled. Work does not only have economic value, but human efforts to get satisfaction and get rewards or wages, in the form of goods and services, will fulfill their life needs. A person's work will affect his economic ability, for that work is a must for every individual because work contains two aspects, physical satisfaction and the fulfillment of life needs. In this regard, Soeroto (2016) provides a definition of work as an activity that produces goods and services for oneself or others, whether people do it for money or not.

Soeroto (2016) explains that by working people will earn income, from the income that the person receives is given to him and his family to consume goods and services resulting from development thus it becomes clearer, whoever is productive, then he has actually participated in real and active in development.

Based on the results of the research and theory above, according to the researcher, the low economy of the community causes them to be unable to access health services, especially obstetrical health at private health facilities or independent practice because they do not have money to pay for doctor's services. Most of the women inpartu are middle class and lower class whose income is uncertain and still below the UMK standard, so they prefer to prioritize household needs rather than having to spend a lot of money for an obstetric check to a specialist.

B. Position of the Fetus in Inpartum Patients at Pragaan Public Health Center, Sumenep Regency

The results showed that almost half of the respondents experienced an anterior fetal position as many as 39 respondents (39\%). In addition, 38 respondents (38\%) had a posterior fetal position. In addition, 15 respondents $(15 \%)$ experienced a transverse fetal position. While a number of 8 respondents $(8 \%)$ experienced a breech fetal position.

In the anterior position, the fetal head is in the hip area and the face is facing the mother's back, while the back is facing the mother's abdomen. In this position, the baby's neck can be freely stretched, so that the chin can bend towards the chest. This position is the most ideal for the birth process. Because, the baby's head that is narrow or small can be a good start to stimulate the opening of the cervix during labor. Usually, the baby is in the anterior position when the gestational age enters the 33-36 week (Helma, 2011).

The fetus is said to be in a posterior position if its head is down or in the hip area, but the baby's face is facing the mother's belly. Meanwhile, the back is facing the mother's back. This position limits the movement of the fetal neck, making it a little more difficult to bend the chin towards the chest. This can make it more difficult for the baby to come out during labor. The fetus is more likely to be in a posterior position if the mother spends too much time sitting or lying down. Usually, this condition occurs in mothers who were instructed by the doctor during their pregnancyforbed rest (Jihan, 2014).

The transverse position can also be referred to as the transverse lie position. In this position, the fetus is in a horizontal position, transversely in the uterus. Most fetuses will change this position a few weeks or days before delivery. However, if the time of delivery arrives and the baby's position does not change, then labor should be performed withCaesarean section. Because if you are forced to give birth normally, there is a risk that the baby's umbilical cord will come out before the baby and that can be dangerous (Kelvin, 2012). 
Breech position Posisiis the opposite of the anterior and posterior positions. According toAmerican Pregnancy (2015), This is the position of the baby in the stomach that is common in pregnancy. 1 in 25 pregnant women can experience it. In this position, the feet of the fetus are down, close to the birth canal, while the head is up, close to the mother's chest.

The position of the baby in a breech stomach can increase the risk of the fetus being entangled in the umbilical cord. This condition can cause injury if the delivery is done vaginally. To change the position of a breech baby, the doctor will usually suggest the EVC technique (external cephalic version). During the process, the doctor will monitor the baby's heart rate. If the heart rate decreases and the EVC does not succeed in changing the position of the fetus in the womb, the doctor will recommend a caesarean section (AP, 2015).

According to researchers, as pregnancy progresses, pregnant women will usually feel the movement of the fetus from inside their stomach, whether it's kicking, shifting, or even rotating positions. During the first and second trimesters, changes in fetal position are usually not a major concern. But enteringthird trimester, because the size of the fetus is getting bigger, it will be difficult for him to change position. In fact, the right position is needed for smooth delivery. Because basically a good fetal position will facilitate the delivery process later.

\section{Family Support for Inpartum Patients at Pragaan Health Center Sumenepmen}

The results showed that most of the respondents had family support in the less category as many as 62 respondents (62\%). In addition, 36 respondents (36.0\%) had sufficient family support. While a number of 2 respondents $(2.0 \%)$ had family support in the good category.

According to Friedman (2014) family support is the attitude, action and acceptance of the family towards its members. Family members are seen as an inseparable part of the family environment. The family also functions as a support system for its members and family members view that people who are supportive are always ready to provide help with assistance if needed.

Kane in Friedman (2017) defines family support as a relationship process between the family and the social environment. According to Kuncoro (2017) family support is verbal and non-verbal communication, advice, real help or behavior provided by people who are familiar with the subject in their social environment or in the form of presence and things that can provide emotional benefits or influence. on the behavior of the recipient, in this case the person who feels emotionally supported feels relieved because he is noticed, gets advice or a pleasant impression on him.

Family and community support have a big role in increasing compliance, namely by supervision and giving encouragement to someone. The advantage of family support is that they live in the same house or close to home with mothers and toddlers so that monitoring is more optimal and there is no direct need for transportation costs (Becher, 2014). Families are aware of the importance of obedience in carrying out an activity, especially regarding the visit of mothers and toddlers at the posyandu, it is very necessary to monitor the growth and development of toddlers to become healthy adults.

According to researchers, the family is someone who is very close and has blood or marital status. Family is the main factor in influencing everything that will be done by someone. So that family support will be very important given to someone, especially pregnant women. Based on the results of the study, it was found that most of the respondents had family support in the category of less where the lack of support lies in emotional support and informational support. Due to busy family due to work so rarely have more time for other family members.

D. Incidence of Premature Rupture of Membranes in Inpartum Patients at Pragaan Health Center, Sumenep Regency

The results showed that the majority of respondents experienced premature rupture of membranes as many as 56 respondents (56\%). Meanwhile, 44 respondents (44\%) did not experience premature rupture of membranes.

Premature rupture of membranes is a rupture of the membranes before there are signs of starting labor and waiting an hour before labor occurs (Manuaba, 2014). Premature rupture of membranes is the rupture of the membranes before labor begins at any stage of pregnancy (Arma, et al 2015). Meanwhile, according to (Sagita, 2017) premature rupture of membranes is characterized by discharge in the form of water from the vagina after 22 weeks of pregnancy and can be declared premature rupture occurs before the delivery process takes place. Fluid comes 
out through the tearing of the amniotic sac, appearing after 28 weeks of gestation and at least one hour before the actual time of pregnancy. Under normal circumstances, 8-10\% of pregnant women at term will experience PROM. So premature rupture of membranes is the rupture of the membranes before the time of delivery.

Premature rupture of membranes can affect pregnancy and childbirth. The distance between the rupture of membranes and the onset of labor is called the latent period or the lag period. There are several calculations that measure the Lag Period, including 1 hour or 6 hours before intrapartum, and above 6 hours after the membranes rupture. If the latent period is too long and the membranes have ruptured, infection can occur in both the mother and the baby (Fujiyarti, 2016).

Rupture of the amniotic membrane is caused by a loss of elasticity at the edge of the amniotic membrane tear. This loss of elasticity of the amniotic membrane is closely related to the collagen network, which can occur due to thinning by infection or low levels of collagen. Collagen in the membrane is found in the amnion in the compact layer, fibroblasts and in the chorion in the reticular layer or trophoblast (Mamede et al., 2012).

The amniotic membrane ruptures because in certain areas there are biochemical changes that cause the amniotic membrane to weaken. Changes in the structure, number of cells and collagen catabolism cause the activity of collagen to change and cause the membranes to rupture. The area around the rupture of the membranes was identified as a "restricted zone of extreme altered morphology (ZAM)" (Rangaswamy, 2012).

Research by Malak and Bell in 1994 found an area called "high morphological change" in the amniotic membrane in the area around the cervix. This area is $2-10 \%$ of the total surface of the amniotic membrane. Bell and colleagues further found that this area is characterized by an increase in MMP-9, an increase in trophoblast apoptosis, a difference in membrane thickness, and an increase in myofibroblasts (Rangaswany et al, 2012).

Research by (Rangaswamy et al, 2012), supporting the concept of the paracervical weak zone, found that the membranes in the paracervical region would rupture with only $20-50 \%$ of the force required for tears in other areas of the membranes. Various studies support the concept of a different zone of the amniotic membrane, especially the zone around the cervix which is significantly weaker than the other zones along with changes in the biochemical and histological composition. This paracervical weak zone has appeared before the rupture of the membranes and acts as an initial breakpoint (Rangaswamy et al, 2012).

Another study by (Reti et al, 2012), showed that the amniotic membrane in the supracervical region showed increased activity of apoptotic protein markers, namely cleavedcaspase-3, cleaved-caspase-9, and decreased Bcl-2. It was found that the rate of apoptosis was found to be higher in the amnion of patients with premature rupture of membranes than patients without premature rupture of membranes, and the rate of apoptosis was found to be highest in the area around the cervix compared to the fundus area (Reti et al, 2012).

Apoptosis that occurs in the mechanism of PROM can be through intrinsic and extrinsic pathways, and both can induce activation of caspases. The intrinsic pathway of apoptosis is the dominant pathway in the apoptosis of the amniotic membrane in term pregnancy. In this study, it was proved that there were significant differences in levels of Bcl-2, cleaved caspase-3, cleaved caspase-9 in the supracervical region, where these proteins are proteins that play a role in the intrinsic pathway. Fas and its ligand, Fas-L which initiates extrinsic pathway apoptosis were also found in all samples of amniotic membranes but their expression did not differ significantly between supracervical and distal regions. It is suspected that the extrinsic pathway does not play a major role in amniotic membrane remodeling (Reti et al, 2012).

According to researchers, the occurrence of premature rupture of membranes can be caused by many things ranging from internal or external factors to the mother and fetus. Of course, all pregnant women do not want to experience premature rupture of membranes, so many take care of their wombs to avoid this. However, many do not know what causes premature rupture of membranes so that pregnant women sometimes unknowingly cause this incident. The impact of premature rupture of membranes if not immediately treated for the mother is infection with germs from outside, and premature or preterm delivery, while the impact on the fetus is blood circulation disorders or the umbilical cord which can cause fetal distress and fetal death 
due to compression of the umbilical cord and oligohydramnios. (amniotic fluid is less than the amount needed or even exhausted).

E. The Effect of Economic Status on the Occurrence of Premature Rupture of Membranes in Inpartum Patients at Pragaan Health Center, Sumenep Regency

Based on the results of the Logistics Regression analysis shows that the p-value is 0.002 $<0.05$, then $\mathrm{H} 1$ is accepted so it can be concluded that there is the effect of economic status on the incidence of premature rupture of membranes in inpartu patients at Pragaan Health Center, Sumenep Regency

Work will determine socioeconomic status because from work all needs will be fulfilled. Work does not only have economic value, but human efforts to get satisfaction and get rewards or wages, in the form of goods and services, will fulfill their life needs. A person's work will affect his economic ability, for that work is a must for every individual because work contains two aspects, physical satisfaction and the fulfillment of life needs. In this regard, Soeroto (2016) provides a definition of work as an activity that produces goods and services for oneself or others, whether people do it for money or not.

Soeroto (2016) explains that by working people will earn income, from the income that the person receives is given to him and his family to consume goods and services resulting from development thus it becomes clearer, whoever is productive, then he has actually participated in real and active in development.

According to the theory expressed by Weni (2010), the purpose of nutrition management for pregnant women is to achieve optimal maternal nutritional status so that mothers undergo pregnancy safely, give birth to babies with good physical and mental potential. So to anticipate things that are not desirable, it is necessary to have a diet and nutritional status in pregnant women. If in the early stages of pregnancy malnutrition occurs, it will greatly affect the development and capacity of the embryo to maintain pregnancy. Malnutrition also causes several pregnancy diseases to arise such as: abortion, fetal death and disability and infection.

A person's economy affects the choice of food that will be consumed daily. A person with a high economy then becomes pregnant, it is very likely that the nutrition needed will be fulfilled, plus an examination will make the mother's nutrition more monitored People with low economic status tend to be more pressing to meet nutritional needs and more important to meet more important needs (Yusuf, 2012).

F. The Effect of Fetal Position on the Occurrence of Premature Rupture of Membranes in Inpartum Patients at Pragaan Health Center, Sumenep Regency

Based on the results of the Logistics Regression analysis shows that the p-value is 0.005 $<0.05$ then $\mathrm{H} 1$ is accepted so it can be concluded that there is the effect of fetal position on the incidence of premature rupture of membranes in inpartu patients at the Pragaan Health Center, Sumenep Regency.

Premature rupture of membranes is very dangerous for pregnant women and their babies. The danger of premature rupture of membranes is infection occurs in the mother and baby. The rupture of the membranes leaves the baby unprotected by the amniotic membrane and exposed to contact with the outside world, which causes bacteria to enter the mother's womb and infect both mother and baby. This can be life threatening for both mother and baby. In addition, the birth of a baby that is less than the normal time causes premature babies and the risk of fetal defects is high (Kompasiana, 2014).

Premature rupture of membranes is a problem that still occurs in obstetrics. Many factors can cause premature rupture of membranes, including breech, preeclampsia, anemia, gemeli and hydramnios. These factors are factors that cause maternal and infant mortality. Then the most dominant cause of premature rupture of membranes is anemia at PKU Muhammadiyah Hospital Surakarta (Huda, 2013).

Huda (2013) explained the results that breech had a significant effect on premature rupture of membranes at PKU Muhammadiyah Surakarta Hospital. Because the buttocks with the legs folded are larger than the head which allows the uterus to increase in tension, thereby causing the membranes to rupture prematurely.

Fetal position abnormalities (malpresentation) can be a factor in the incidence of PROM. One example of malpresentation is the breech position. In the breech location, the buttocks 
occupy the uterine cervix, with this condition the fetal movement occurs in the lowest part because of the presence of the fetal feet occupying the uterine cervix while the fetal head will press the uterine fundus which can compress the diaphragm and this situation causes a feeling of tightness in pregnant women which can increase intrauterine pressure tension, causing PROM (Antonius, 2007). The results of Wulandari's research in 2016 showed that there was a relationship between fetal position abnormalities and the incidence of premature rupture of membranes $(\mathrm{p}<0.05 ; \mathrm{OR}=6.942$. This means that mothers who experience fetal position abnormalities are at risk of 6 .

G. The Effect of Family Support on the Incidence of Premature Rupture of Membranes in Inpartum Patients at Pragaan Health Center, Sumenep Regency

Based on the results of the Logistics Regression analysis shows that the p-value is 0.012 $<0.05$ then $\mathrm{H} 1$ is accepted so it can be concluded that there is the effect of family support on the incidence of premature rupture of membranes in inpartu patients at the Pragaan Health Center, Sumenep Regency.

Wills (2018) concludes that buffer effects (social support protects individuals against the negative effects of stress) and primary effects (social support directly affects health outcomes) are found. Indeed, the main and buffering effects of social support on health and well-being may function simultaneously. More specifically, the presence of adequate social support has been shown to be associated with reduced mortality, easier recovery from illness and among the elderly, cognitive function, physical and emotional health.

Kuncoro (2017) argues that family support includes two things, namely the number of available support sources and the level of satisfaction with the support received. The amount of support available is an individual's perception of a number of people who can be relied on when the individual needs help. The level of satisfaction with the support received is related to the individual's perception that his needs will be met (quality-based approach).

According to Kuncoro (2017) there are two sources of family support, namely natural and artificial. Natural family support is received by a person through spontaneous social interactions in his life with the people around him, for example family members (children, wife, husband, relatives), close friends or relations. This family support is non-formal, while artificial family support is support designed into a person's primary needs, for example family support due to natural disasters through various donations.

Provide support both emotional and in the form of information provided in the form of being ready to help, willing to listen, attentive to patient needs and providing an appropriate environment for patients to share their care experiences. In addition, providing support helps increase the patient's confidence to continue with care activities. Thorsteinson (2016) states that mothers of toddlers listening to someone's feelings and holding hands are examples of how to support and encourage patients. Ensuring environmental conditions that can motivate patients benefit in improving midwifery competence and are useful for facilitating the relationship between health workers and toddlers and their families.

H. The Most Influential Factors Towards The Incidence Of Premature Rupture In Inpartu Patients At Pragaan Health Center Sumenep Regency

Based on the results of the Logistics Regression analysis shows that the p-value is 0.002 $<0.05$, then $\mathrm{H} 1$ is accepted so it can be concluded that there is the effect of economic status on the incidence of premature rupture of membranes in inpartu patients at Pragaan Health Center, Sumenep Regency

Pregnancy is a moment that is highly desired by husband and wife. This can make the family more harmonious because it has a child who is always coveted. But in reality, sometimes pregnancy is accompanied by several obstacles such as premature rupture of membranes. Premature rupture of membranes is the process of rupture of the membranes before the start of labor or delivery time that is more than 37 weeks or less than 36 weeks (Manuaba, 2014). Then Prawirohardjo (2015) also said that premature rupture of membranes is a state of rupture of the amniotic membranes before delivery where the gestational age has not reached 36 weeks.

Premature rupture of membranes or spontaneous / early / premature rupture of the membrane (PROM) is a rupture of the membranes in inpartu mothers, namely when the opening in primiparas is less than $3 \mathrm{~cm}$ and in multiparas less than $5 \mathrm{~cm}$, regardless of gestational age 
(Nugroho, 2012). Premature rupture of membranes can occur late in pregnancy or long before delivery. The incidence of premature rupture of membranes in some areas is high, this is evidenced by the high number of referrals with cases of premature rupture of membranes by village midwives to hospitals with more adequate health facilities.

Premature rupture of membranes is very dangerous for pregnant women and their babies. The danger of premature rupture of membranes is infection occurs in the mother and baby. The rupture of the membranes leaves the baby unprotected by the amniotic membrane and exposed to contact with the outside world, which causes bacteria to enter the mother's womb and infect both mother and baby. This can be life threatening for both mother and baby. In addition, the birth of a baby that is less than the normal time causes premature babies and the risk of fetal defects is high (Kompasiana, 2014).

The cause of premature rupture of membranes is not known with certainty, but it is possible that the predisposing factor is infection that occurs directly in the amniotic membrane or ascending from the vagina or cervix. In addition, abnormal amniotic membrane physiology, incompetent cervix, fetal position abnormalities, age of women less than 20 years and above 35 years, multigravidity/parity factors, smoking, socioeconomic conditions, antepartum bleeding, history of abortion and previous preterm delivery, history of amniotic fluid previous premature rupture, nutritional deficiencies, namely copper or ascorbic acid, excessive uterine tension, narrowing of the pelvis, maternal fatigue at work, and trauma obtained such as a history of sexual intercourse in the third trimester, internal examination and amniocentesis (Prawirohardjo, 2014).

Huda (2013) explained the results that breech had a significant effect on premature rupture of membranes at PKU Muhammadiyah Surakarta Hospital. Because the buttocks with both legs folded are larger than the head which allows the uterus to increase in tension, thereby causing the membranes to rupture prematurely.

Inadequate family economic conditions cause pregnant women and fetuses to be less able to get what they really need to support the health of the mother and fetus. The position of the fetus that is not suitable can also cause premature rupture of the membranes. And also family support plays an important role in meeting the needs of the mother and fetus where the family will fully assist everything that is needed by the mother and fetus during the early pregnancy until the delivery process. So that these factors become very important considering that pregnant women can experience premature rupture of membranes (Mulyanto, 2015).

\section{CONCLUSION}

1. Almost half of the respondents have economic status middle class category as many as 42 respondents $(42 \%)$.

2. Almost half of the respondents experienced an anterior fetal position as many as 39 respondents (39\%).

3. Most respondents have family support in the less category as many as 62 respondents (62\%).

4. Most of the respondents experienced premature rupture of membranes as many as 56 respondents $(56 \%)$.

5. There is the effect of economic status on the incidence of premature rupture of membranes in inpartu patients at Pragaan Health Center, Sumenep Regency

6. Ada the effect of fetal position on the incidence of premature rupture of membranes in inpartu patients at Pragaan Health Center, Sumenep Regency

7. Ada the effect of family support on the incidence of premature rupture of membranes in inpartu patients at the Pragaan Health Center, Sumenep Regency.

\section{SUGGESTION}

1. For Respondents

It is hoped that both pregnant women can manage their needs and things that must be done during pregnancy until delivery, starting from maintaining a lifestyle and even monitoring the development of the fetus in order to reduce the incidence of KTD.

2. For Educational Institutions

It is hoped that educational institutions can use the results of this study as learning input in the influence of economic status, fetal position and family support on the incidence of 
premature rupture of membranes in inpartu patients at the Pragaan Health Center, Sumenep Regency and can be developed again for further research to be more useful for readers and for researchers.

3. For Further Researchers

It is hoped that further research needs to be deepened and added more specific research on Analysis of factors that influence fetal position in inpartu patients at Pragaan Health Center, Sumenep Regency

4. For Health Center

It is hoped that the puskesmas can use the results of this study as input for internal learning to reduce the incidence of premature rupture of membranes in inpartu patients at the Pragaan Health Center, Sumenep Regency.

\section{ACKNOWLEDGMENT}

I solemnly declare that to the best of my knowledge, in this thesis there is no scientific work that has been submitted by another person to obtain an academic degree at a university, and there is no work or opinion that has been written or ordered by anyone. others, except those quoted in this manuscript and mentioned in the citation sources and bibliography.

\section{CONFLICT OF INTEREST}

In this study, there is no interest whatsoever regarding myself or with other institutions other than the Indonesian Strada Institute of Health Sciences, Kediri City.

\section{REFERENCES}

Alim, S. E. and Ramadhian, R. (2016) 'Penatalaksanaan Mual dan Muntah pada Hiperemesis Gravidarum Sugma', $J$ Medula Unila, 5(1), pp. 131-134. Available at: https://studylibid.com/doc/615183/penat alaksanaan-mual-dan-muntah-pada-hipere mesisgravidarum.

Fujiyarti (2016) 'Gambaran Dukungan Keluarga Terhadap Ibu Hamil Dengan Hiperemesis Gravidarum'. Yogyakarta. Available at: http://repository.umy.ac.id/bitstream/han dle/123456789/2776/naskah publikasi.pdf?sequence=11\&isAllowed=y.

Huda, I., Putra, H. K. and Thaib, S. H. (2013) 'Hubungan Hiperemesis Gravidarum dengan Usia Ibu, Usia Gestasi, Paritas, dan Pekerjaan pada Pasien Rawat Inap di RSUP Dr. Moh. Hoesin Palembang', Jurnal Kedokteran dan Kesehatan, 3(3), pp. 166-171.

Jihan, R. H. and Qomariah, Si. (2014) 'The Vitamin B6 Content of Kepok Banana: an Alternative to Overcome Nausea for Pregnant Women Kandungan Vitamin B6 Pada Pisang Kepok: Alternatif Mengatasi Mual Muntah Pada Ibu Hamil', Jurnal Kesehatan Komunitas, 3(5), pp. 193-195. Availableat: http://jurnal.htp.ac.id/index.php/keskom /article/view/166.

Kuncoro, F. R. N. (2017) 'Hubungan Karakteristik dan Psikologi Ibu Hamil dengan Hiperemesis Gravidarum di RSUD H Abd manan Simatupang Kisaran', Wahana Inovasi, 6(1), pp. 202-212.

Latifah, L., Setiawati, N. and Dwi, E. H. (2017) 'Efektifitas Self Management Module dalam Mengatasi Morning Sickness Effectiveness Self Management Module in Overcoming Morning Sickness', Jurnal Keperawatan Fikkes UnSoed, 5(1), pp. 10-18. Available at: https://media.neliti.com/media/publicatio ns/105988-ID-efektifitas-self-management- moduledalam.pdf.

Manuaba, A. S. (2014) 'Hubungan Umur dan Paritas Ibu Hamil dengan Kejadian Hiperemesis Gravidarum', Jurnal Ilmiah Kesehatan Diagnosis, 12(6), pp. 598-602.

Mulyanto, E. (2015) 'Usia dan Paritas terhadap Kejadian Hiperemesis Gravidarum di RSUD Dokter Rubini Mempawah', Jurnal Kebidanan Khatulistiwa, 1(2), pp. 60-65.

Mulyanto, F. I., Rahayu, D. E. and Utami, R. (2015) 'Efektifitas Pemberian Serbuk Jahe (Zingiber Officinale) terhadap Tingkatan Mual Muntah pada Ibu Hamil', Jurnal Ilmu Kesehatan, 4(1), pp. 18-30. Available at: file://C:/Users/USER/Downloads/docu ment (1).pdf.

Nugroho, R. R. (2012) 'Efektivitas Pemberian Seduhan Jahe Dengan Jus Buah Jeruk Bali Terhadap Frekuensi Mual Muntah Ibu Hamil Trimester 1', in Prosiding Seminar Nasional Kesehatan, p. 30. Available at: http://prosiding.akbiduk.ac.id/assets/doc /170602084413-3.pdf. 
Prawirohardjo, D. A., Widyawati, S. A. and Yuswantina, R. (2014) 'Hubungan Dukungan Suami dengan Kejadian Hiperemesis Gravidarum di Rumah Sakit Umum Daerah Ambarawa'. Availableat: https://studylibid.com/doc/1132986/hubu ngan-dukungan-suami-dengan-kejadian

Rangaswany, S. (2017) 'Kualitas Pelayanan dan Kepuasan Pasien Rumah Sakit: Kasus Pada Pasien Rawat Jalan', Jurnal Medicoeticolegal dan Manajemen Rumah Sakit, 6(1), pp. 9-14. doi: 10.18196/jmmr.6122.Kualitas.

Soeroto, Megamaulia, L. and Widia, L. (2016) 'Hubungan antara Status Gizi Ibu Hamil dengan Hyperemesis Gravidarum di RSIA Paradise Kabupaten Tanah Bumbu', Jurnal Darul Azhar, $1(1)$, pp. 51-56.

Syamsuddin, S., Lestari, H. and Fachlevy, A. F. (2018) 'Hubungan antara Gastritis , Stres, dan Dukungan Suami Pasien dengan Sindrom Hiperemesis Gravidarum di Wilayah Kerja Puskesmas Poasia Kota Kendari The Correlation Between Gastritis, Stress , and Housband Support of Patients Health Center Poasia Kendari Ci', Jurnal Penelitian dan Pengembangan Pelayanan Kesehatan, 2(2), pp. 102-107.

Zuhrotunida and Yudiharto, A. (2017) 'Hubungan Dukungan Keluarga dengan Kecemasan Ibu Hamil Menghadapi Proses Persalinan di Puskesmas Kecamatan Mauk Kabupaten Tangerang Tahun 2016', Jurnal JKFT Universitas Muhammadiyah Tangerang, 2, pp. 60-70. 